\title{
Synthesis of the impurities during the manufacture of bulk drug midazolam and separation of these impurities by HPLC
}

\author{
BHAWANA SATI ${ }^{1 *}$ \\ HEMLATA SATI ${ }^{2}$ \\ SARLA SAKLANI ${ }^{2}$ \\ ELLAMMA $^{3}$ \\ PRAKASH CHANDRA BHATT ${ }^{4}$ \\ RAVINESH MISHRA ${ }^{5}$ \\ ${ }^{1}$ Department of Pharmacy, Banashtali \\ University, Banashtali, Rajasthan, India \\ ${ }^{2}$ Department of Pharmaceutical Sciences \\ H. N. B. Garhwal University, Srinagar \\ Garhwal, Uttarakhand, India \\ ${ }^{3}$ East Point College of Pharmacy \\ Bidarahalli, Virgonagar Post, Bangalore \\ Karnataka, India \\ ${ }^{4}$ Indian Medicines Pharmaceutical \\ Corporation Ltd, Mohan, Ramnagar, India \\ ${ }^{5}$ Institute of Pharmacy and Emerging Sciences \\ Baddi University of Emerging Science and \\ Technology, Makhnumajra Baddi, Distt. Solan \\ Himachal Pradesh India
}

\begin{abstract}
During the manufacture of bulk drug midazolam various impurities arised that can be the related products or degradation products. Structures of eight impurities that can arise during the manufacture of bulk drug midazolam were proposed. In the present work, synthesis of these impurities and their characterization by different spectroscopic techniques have been done. HPLC method was developed for the separation of impurities from the bulk drug. The developed method separates midazolam from its eight impurities/degradation products within a run time of $45 \mathrm{~min}$.
\end{abstract}

Keywords: midazolam, impurities, degradation products, HPLC method

Impurities can be closely related to the product that is formed during the synthesis of a bulk drug or it can be decomposition product formed during the storage of the drug. The International Conference on Harmonization (ICH) has published guidelines on impurities in new drug substances, products and residual solvents. According to ICH guidelines, an impurity should not exceed $0.1 \%$ and total impurity should not exceed $1.0 \%$ in manufacturing each batch of the drug $(1,2)$. Impurities present in excess of $0.1 \%$

\footnotetext{
*Correspondence; e-mail: bhawanasati28@gmail.com
} 
should be identified and quantified by sufficiently selective methods. The process of identification and quantification of impurities is known as impurity profiling. The procedure of impurity profiling begins with the detection of impurities using thin layer chromatography, high-performance liquid chromatography or gas chromatography (3). The presence of impurities in bulk drug can be identified by using the impurity reference standard, which includes the products of predictable side reactions or degradation products (4). If the retention time of both (impurities present in the bulk drug and impurity reference standard) match, then the impurities present will be easily identified. In case of unsuccessful identification, an analytical method, either LC/MS or GC/MS, is used. Based on MS information, the structure of the impurity will be proposed. The important step in impurity profiling is the synthesis of the material (impurity standard) with the proposed structure. Retention and spectral matching of the synthesized material with the impurity present in the bulk drug are useful for the analytical method development and validation. It is essential to know the structure of impurities present in the bulk drug in order to alter the reaction conditions and to reduce the quantity of impurity to an acceptable level.

Midazolam is 8-chloro-6-(2-fluorophenyl)-1-methyl-4H-imidazo [1,5-a][1,4]-benzodiazepine. It is used as a powerful anxiolytic, hypnotic, anticonvulsant, skeletal muscle relaxant and sedative agent (5-8). In the manufacture of the bulk drug midazolam, eight new impurities were proposed, which can arise due to side reactions or can be related or degradation products.

Literature survey revealed various HPLC methods for determination of midazolam and its metabolites in biological fluids (9-13). Based on the literature survey, an attempt was made to synthesize the proposed impurities of midazolam and to use a RP-HPLC method for separation of these eight impurities from the bulk drug midazolam.

\section{EXPERIMENTAL}

\section{Apparatus and instruments}

All melting points are uncorrected and were measured using a Büchi Digital auto melting point apparatus (Büchi Corporation, Japan). IR spectra were recorded as potassium bromide pellets on a Shimadzu-FTIR $8400 \mathrm{~S}$ spectrophotometer (Japan). ${ }^{1} \mathrm{H}$ NMR was obtained with a Bruker Spectrospin-200 NMR spectrometer (Bruker, Germany) in $\mathrm{CDCl}_{3}$ and dimethylsulfoxide (DMSO) as solvents, using TMS as internal reference. Mass spectra were recorded on a Shimadzu GC/MS spectrometer 210. Follow-up of the reactions and purity checking of the compounds were done by TLC on silica gel-coated aluminum sheets. Column chromatography was carried out on silica gel $(0.15-0.25 \mathrm{~mm}$, column size i.d. $4 \times 90 \mathrm{~cm}$ ) (Merck, Germany) and mixture of all impurities from the midazolam was studied using the instrument Shimadzu alliance HPLC, Rheodyne injector.

\section{Materials}

Midazolam and 2-aminomethyl-7-chloro-2,3-dihydro-5-(2-fluorophenyl)-1H-1,4benzodiazepine hydrochloride salt were provided Microlabs (India). Dipotassium hy- 
B. Sati et al: Synthesis of the impurities during the manufacture of bulk drug midazolam and separation of these impurities by HPLC, Acta Pharm. 63 (2013) 385-396.

drogen phosphate buffer (Qualigens Fine Chemicals, India), orthophosphoric acid (Qualigens Fine Chemicals, India), methanol (HPLC grade, Qualigens Fine Chemicals) and acetonitrile (HPLC grade Qualigens Fine Chemicals) were used. All other chemicals were of analytical grade and were purchased from S.D. Fine Chem. Ltd, India.

\section{Syntheses}

8-Chloro-6-(2-fluorophenyl)-1-methyl-5,6-dihydro-4H-imidazo[1,5-a][1,4]imidazo[1,5-a] [1,4]-benzodiazepine (IMP 1). - A mixture of 8-chloro-6-(2-fluorophenyl)-1-methyl-4H-imidazo[1,5-a][1,4]-benzodiazepine (11.2 g, $0.03 \mathrm{~mol})$, dichloromethane (300 $\mathrm{mL})$, glacial acetic acid $(300 \mathrm{~mL})$ and $\mathrm{Zn}$ dust $(12 \mathrm{~g}, 0.18 \mathrm{~mol})$ was stirred for $3 \mathrm{~h}$ at room temperature (under TLC control). Inorganic material was filtered off from the reaction mixture and washed with dichloromethane and water. The filtrate was diluted with dichloromethane $(400 \mathrm{~mL})$, water $(800 \mathrm{~mL})$ and made alkaline with ammonia solution $(25 \%)$. The dichloromethane layer was separated, dried over sodium sulphate, evaporated and the residue was crystallized from hexane to give IMP 1.

8-Chloro-6-(2-fluorophenyl)-1-methyl-6H-imidazo[1,5-a][1,4]-benzodiazepine (IMP 2). - A mixture of midazolam $(15.0 \mathrm{~g}, 0.05 \mathrm{~mol})$, dichloromethane $(180 \mathrm{~mL})$ and potassium terc-butoxide $(6 \mathrm{~g})$ was stirred using a magnetic stirrer and cooled to $-30{ }^{\circ} \mathrm{C}$. The dark mixture was acidified with glacial acetic acid $(30 \mathrm{~mL})$ and poured into water $(500 \mathrm{~mL})$. Dichloromethane $(250 \mathrm{~mL})$ was added to the reaction mixture and neutralized with sodium bicarbonate. The organic layer (dichloromethane) was collected and the aqueous phase was extracted with dichloromethane $(250 \mathrm{~mL})$. The organic layers were combined and washed with water, dried over sodium sulfate and evaporated. The residue was chromatographed over silica gel using dichloromethane as an eluent. The fractions were combined, evaporated and the residue was crystallized from ethyl acetate to yield the final product.

8-Chloro-6-(2-fluorophenyl)-1-methyl-4H-imidazo[1,5-a][1,4]benzodiazepine-5-oxide (IMP 3). - A mixture of midazolam $(15.6 \mathrm{~g}, 0.478 \mathrm{~mol})$, dichloromethane $(320 \mathrm{~mL})$ and $\mathrm{m}$-chloroperbenzoic acid $(19 \mathrm{~g}, 0.11 \mathrm{~mol})$ was stirred for 2 hours at room temperature (under TLC control). The reaction mixture was extracted with $1 \mathrm{~mol} \mathrm{~L}^{-1} \mathrm{HCl}(450 \mathrm{~mL})$. The acidic layer was collected, washed with dichloromethane $(100 \mathrm{~mL})$, neutralized by adding ammonia solution (25\%) and extracted with dichloromethane. The dichloromethane layer was collected, washed with water $(50 \mathrm{~mL})$, dried and evaporated. The residue obtained was crystallized from ethyl acetate to give the product, which was further purified by column chromatography over silica gel using dichloromethane as an eluent. Clean fractions were combined, evaporated and the residue was crystallized from ethyl acetate and yielded colorless crystals of compound IMP 3.

2-Aminomethyl-7-chloro-2,3-dihydro-5-(2-fluorophenyl)-1H-1,4-benzodiazepine hydrochloride salt (IMP 4). - A mixture of 2-aminomethyl-7-chloro-2,3-dihydro-5-(2-fluorophenyl)$1 \mathrm{H}$-1,4-benzodiazepine dimaleate salt $(50.0 \mathrm{~g}, 0.05 \mathrm{~mol})$, water $(100 \mathrm{~mL})$ and dichloromethane $(100 \mathrm{~mL})$ was taken and stirred for 1 hour till the dimaleate salt fully dissolved. The reaction mixture was neutralized using ammonia solution (25\%) and the DCM layer was separated; the aqueous layer was extracted with dichloromethane $(100 \mathrm{~mL})$. Dichloromethane layers were combined, washed with water $(100 \mathrm{~mL})$, dried over so- 
B. Sati et al: Synthesis of the impurities during the manufacture of bulk drug midazolam and separation of these impurities by HPLC, Acta Pharm. 63 (2013) 385-396.

dium sulfate and evaporated at reduced pressure until thick oil was obtained. The oil was dissolved in acetone $(50 \mathrm{~mL})$ and a mixture of conc. $\mathrm{HCl}$ and isopropanol (1:1) was added till the final $\mathrm{pH}$ reached 2 . The reaction mixture was cooled to $10{ }^{\circ} \mathrm{C}$, the precipitate obtained was filtered off and dried to give IMP 4.

N-desalkylflurazepam (IMP 5). - Step 1. A mixture of 2-amino-5-chloro-2'-fluoro benzophenone $(23.0 \mathrm{~g}, 0.01 \mathrm{~mol})$, sodium bicarbonate $(13.0 \mathrm{~g})$ and dry toluene $(70.0 \mathrm{~mL})$ was stirred at $45{ }^{\circ} \mathrm{C}$. A solution of chloroacetyl chloride $(24.0 \mathrm{~mL}, 0.03 \mathrm{~mol})$ in toluene $(10$ $\mathrm{mL}$ ) was added dropwise under constant stirring at $50-55{ }^{\circ} \mathrm{C}$ and after complete addition, the temperature was raised to $70{ }^{\circ} \mathrm{C}$. Stirring was continued for one hour (under TLC control). The reaction mixture was cooled and poured into ice cold water under constant stirring. The precipitate obtained was filtered, washed with toluene, water, hexane and crystallized from methanol to give the compound 2-(2-chloro acetamido)-5chloro-2'-fluoro benzophenone (1) as off-white crystals.

Step 2. A mixture of 2-(2-chloro acetamido)-5-chloro-2'-fluoro benzophenone (1) $(15.0 \mathrm{~g}, 0.1 \mathrm{~mol})$ and ammonia solution $(25 \%, 3.4 \mathrm{~mL})$ in methanol $(23.8 \mathrm{~mL})$ was refluxed (under TLC control) till the completion of reaction. Methanol was removed under vacuum and the residue was diluted with water. The residue was filtered and washed with water and methanol. The product obtained was crystallized from methanol (decolorizing carbon was added) to give IMP 5 as a white crystalline solid.

6-Chloro-2-methyl-4-(2-fluorophenyl) quinazoline (IMP 6). - Step 1. A mixture of acetaldehyde $(23 \mathrm{~mL})$ and $1.5 \mathrm{~mol} \mathrm{~L}-1 \mathrm{HCl}(16 \mathrm{~mL})$ was stirred for 1 hour at $5^{\circ} \mathrm{C}$. The above solution was added to a mixture of 2-amino-5-chloro-2'-fluorobenzophenone (20 g, 0.09 $\mathrm{mol})$, hydroxylamine sulphate $(7.2 \mathrm{~g}, 0.042 \mathrm{~mol})$ and ethanol $(95 \%, 88 \mathrm{~mL})$. The reaction mixture was stirred for 24 hours (under TLC control) and poured off into crushed ice $(300 \mathrm{~g})$ and water $(400 \mathrm{~mL})$. The precipitate of 6-chloro-2-methyl-4-(2-fluorophenyl)-1,2-dihydroquinazoline 3-oxide (2) formed was filtered and dried.

Step 2. To a mixture of 6-chloro-2-methyl-4-(2-fluorophenyl)-1,2-dihydroquinazoline-3-oxide (2) (10 g, $0.07 \mathrm{~mol})$ and dichloromethane $(350 \mathrm{~mL}, 0.27 \mathrm{~mol})$, activated manganese dioxide ( $30 \mathrm{~g}, 0.08 \mathrm{~mol})$ was added and the reaction mixture was stirred under reflux for 3 hours (under TLC control). The reaction mixture was filtered through celite, washed with a 50:50 $(\mathrm{V} / \mathrm{V})$ mixture of dichloromethane and methanol (300 $\mathrm{mL})$. The combined filtrates were evaporated and 6-chloro-2-methyl-4-(2-fluorophenyl) quinazoline 3-oxide (3) was crystallized from methanol.

Step 3. A mixture of 6-chloro-2-methyl-4-(2-fluorophenyl) quinazoline-3-oxide (3) $(10 \mathrm{~g}, 0.034 \mathrm{~mol})$ and methanol $(30 \mathrm{~mL})$ was stirred for 1 hour at room temperature. The reaction mixture was cooled $\left(10{ }^{\circ} \mathrm{C}\right)$ and sodium borohydride $(3 \mathrm{~g}, 0.043 \mathrm{~mol})$ was added slowly. Stirring was continued additionally for 24 hours (under TLC control). The reaction mixture was dissolved in methanol. Methanol was removed under vacuum and water $(50 \mathrm{~mL})$ was added to the residue. The reaction mixture was neutralized by adding dilute sulphuric acid and extracted with ethyl acetate. The ethyl acetate layer was collected, dried over sodium sulfate, evaporated and the solid product of 6-chloro-2-methyl-4-(2-fluorophenyl) quinazoline (IMP 6) was obtained.

8-Chloro-6-(2-fluorophenyl)-3a,4,-dihydro-1-methyl-3H-imidazo[1,5-a][1,4]benzodiazepine (IMP 7) - Step 1. 2-Aminomethyl-7-chloro-2,3-dihydro-5-(2-fluoro-phenyl)-1H-1,4-ben- 
B. Sati et al: Synthesis of the impurities during the manufacture of bulk drug midazolam and separation of these impurities by HPLC, Acta Pharm. 63 (2013) 385-396.

zodiazepine dimaleate, $(8.0 \mathrm{~g}, 0.03 \mathrm{~mol})$ was partitioned between dichloromethane and an aqueous ammonia solution ( $5 \%$ ) in a separating funnel. The dichloromethane layer was collected and washed with water, dried over sodium sulfate and evaporated. The residue was dissolved in pyridine $(50 \mathrm{~mL}, 0.6 \mathrm{~mol})$; acetic anhydride $(10 \mathrm{~mL}, 0.1 \mathrm{~mol})$ was added and the mixture was heated over a steam bath for 4 hours. The reagents were evaporated under reduced pressure and the residue was partitioned between dichloromethane and an aqueous sodium bicarbonate solution (10\%). The organic layer was collected, dried and evaporated. Crystallization of the residue from hexane yielded the final product 1-acetyl-2-acetylaminomethyl-7-chloro-2,3-dihydro-5-(2-fluorophenyl)- $1 \mathrm{H}$ -1,4-benzodiazepine (4).

Step 2. A mixture of 1-acetyl-2-acetylaminomethyl-7-chloro-2,3-dihydro-5-(2-fluorophenyl)-1H-1,4-benzodiazepine (4) $(5.0 \mathrm{~g}, 0.01 \mathrm{~mol})$ and polyphosphoric acid (100.0 g) was heated over a water bath $\left(150-170{ }^{\circ} \mathrm{C}\right)$ for 10 minutes. The reaction mixture was cooled, dissolved in ice water and was made alkaline with an ammonia solution (25\%). The precipitated base was extracted with dichloromethane. The extracts were washed with water, dried over sodium sulfate and evaporated. The residue was chromatographed over silica gel using methanol in dichloromethane as an eluent. The pure fractions were combined, evaporated and crystallized from ether to yield the final product.

8-Chloro-6-(2-fluorophenyl)-3a,4,5,6-tetrahydro-1-methyl-3H-imidazo[1,5-a][1,4]benzodiazepine (IMP 8). - A mixture of 8-chloro-6-(2-fluorophenyl)-3a,4-dihydro-1-methyl-3H-imidazo[1,5-a][1,4] benzodiazepine (IMP 7) (11.2 g, $0.034 \mathrm{~mol})$, dichloromethane $(300 \mathrm{~mL})$, glacial acetic acid $(300 \mathrm{~mL})$ and $\mathrm{Zn}$ dust $(12 \mathrm{~g}, 0.18 \mathrm{~mol})$ was stirred for $3 \mathrm{~h}$ at room temperature (under TLC control). The inorganic material was filtered off from the reaction mixture and washed with dichloromethane and water. The filtrate was diluted with dichloromethane $(400 \mathrm{~mL})$, water $(800 \mathrm{~mL})$ and made alkaline with an ammonia solution (25\%). The dichloromethane layer was separated, dried and crystallized from hexane to give IMP 8.

\section{Development of a HPLC method for the separation of the mixture of impurities}

Separation of all eight impurities from the drug midazolam was performed on a column of type $\mathrm{C} 8$, size: $l=0.25 \mathrm{~m}, d=4.0 \mathrm{~mm}, 30^{\circ} \mathrm{C}$. The mobile phase consisted of dipotassium hydrogen phosphate buffer ( $\mathrm{pH}$ adjusted to 3.29 using diluted orthophosphoric acid) /acetonitrile / methanol (71.45: $20.7: 7.85, V / V / V)$. The mobile phase was filtered through a $0.45 \mu \mathrm{m}$ nylon membrane filter and degassed by sonication for about $15 \mathrm{minu}-$ tes prior to use. The flow rate was $1 \mathrm{~mL} \mathrm{~min}^{-1}$, and the injection volume was $20 \mu \mathrm{L}$. SPD-10 AVP UV-visible detector and class VP software was used.

\section{Preparation of midazolam/impurities solutions}

Midazolam/each impurity of midazolam (IMP 1-8) was exactly weighed and dissolved in methanol. Volumetric flasks were sonicated for 5 minutes and the volume was made up with methanol. The stock solution was $0.25 \mathrm{mg} \mathrm{mL}^{-1}$ midazolam and $0.5 \mathrm{mg}$ $\mathrm{mL}^{-1}$ impurity $1,2,3,4,5,6,7$ and 8 , respectively. From the above stock solution, $1 \mathrm{~mL}$ of each impurity was pipetted out into a $25-\mathrm{mL}$ volumetric flask and the volume was made up to the mark with the standard reference solution of midazolam. The mixture 
B. Sati et al: Synthesis of the impurities during the manufacture of bulk drug midazolam and separation of these impurities by HPLC, Acta Pharm. 63 (2013) 385-396.

was sonicated for 5 minutes. $20 \mu \mathrm{L}$ of the solution was injected and the retention time was recorded.

\section{RESULTS AND DISCUSSION}

\section{Chemistry}

An attempt was made to synthesize eight impurities of the bulk drug midazolam and characterize them by physical, chemical and spectral data (Tables I and II). Midazolam could be considered as the starting material for impurities 1, 2 and 3 . Synthesis of

Table I. Physical and chemical properties of synthesized compounds

\begin{tabular}{ccccc}
\hline Code & $\begin{array}{c}\text { Yield } \\
(\%)\end{array}$ & $\begin{array}{c}\text { M.p. } \\
\left({ }^{\circ} \mathrm{C}\right)\end{array}$ & $\begin{array}{c}\text { Mol. formula } \\
\left(M_{\mathrm{r}}\right)\end{array}$ & $\begin{array}{c}\text { Retention } \\
\text { time (min) }\end{array}$ \\
\hline IMP 1 & 68 & 203 & $\mathrm{C}_{18} \mathrm{H}_{15} \mathrm{ClFN}_{3}(327.8)$ & 6.442 \\
IMP 2 & 55 & 181 & $\mathrm{C}_{18} \mathrm{H}_{13} \mathrm{ClFN}_{3}(325.8)$ & 11.258 \\
IMP 3 & 50 & 214 & $\mathrm{C}_{18} \mathrm{H}_{13} \mathrm{ClFN}_{3} \mathrm{O}(341.8)$ & 9.608 \\
IMP 4 & 85 & 255 & $\mathrm{C}_{16} \mathrm{H}_{15} \mathrm{ClFN}_{3}(303.8)$ & 4.442 \\
IMP 5 & 70 & 207 & $\mathrm{C}_{15} \mathrm{H}_{10} \mathrm{ClFN}_{2} \mathrm{O}(288.8)$ & 40.858 \\
IMP 6 & 63 & 142 & $\mathrm{C}_{15} \mathrm{H}_{10} \mathrm{ClFN}_{2}(272.8)$ & 18.867 \\
IMP 7 & 80 & 148 & $\mathrm{C}_{18} \mathrm{H}_{15} \mathrm{ClFN}_{3}(327.8)$ & 13.775 \\
IMP 8 & 65 & 280 & $\mathrm{C}_{18} \mathrm{H}_{17} \mathrm{ClFN}_{3}(329.8)$ & 6.042 \\
\hline
\end{tabular}

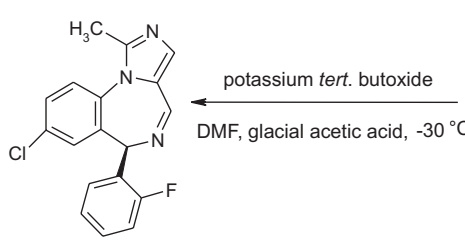

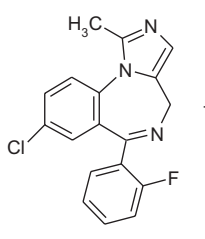

MIDAZOLAM

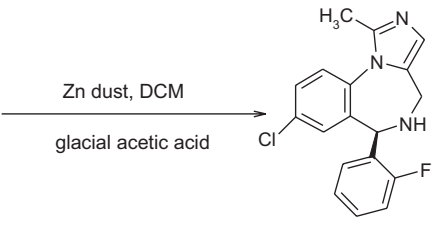

IMP 1

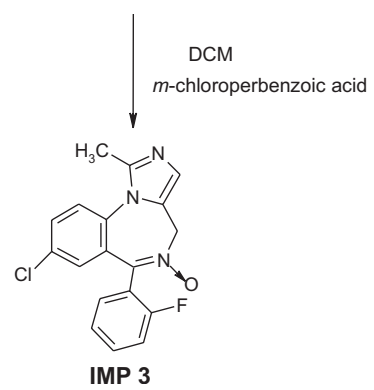

Scheme 1 
B. Sati et al: Synthesis of the impurities during the manufacture of bulk drug midazolam and separation of these impurities by HPLC, Acta Pharm. 63 (2013) 385-396.

Table II. Spectral data of synthesized compounds

\begin{tabular}{|c|c|c|c|}
\hline Code & Mass $(m / z)$ & $\operatorname{IR}\left(v, \mathrm{~cm}^{-1}\right)$ & ${ }^{1} \mathrm{H}$ NMR $(\delta, \mathrm{ppm})\left(\mathrm{CDCl}_{3}, \mathrm{DMSO}\right)$ \\
\hline IMP 1 & $\begin{array}{l}329.2\left(\mathrm{M}^{+}+2\right) \\
327.2\left(\mathrm{M}^{+}\right)\end{array}$ & $\begin{array}{c}3280.69(\mathrm{NH}) \\
1310.54(\mathrm{C}-\mathrm{N}) \\
1089.71(\mathrm{C}-\mathrm{Cl}) \\
1231.46(\mathrm{C}-\mathrm{F})\end{array}$ & $\begin{array}{c}7.7 \text { (br, s, 1H, NH), 6.769-7.39 (m, 8H, ArH), } \\
2.505\left(\mathrm{~s}, 3 \mathrm{H}, \mathrm{CH}_{3}\right), 3.509\left(\mathrm{~d}, 1 \mathrm{H}, \mathrm{CH}_{2}\right) \\
4.036\left(\mathrm{~d}, 1 \mathrm{H}, \mathrm{CH}_{2}\right), 5.147(\mathrm{~s}, 1 \mathrm{H}, \mathrm{CH})\end{array}$ \\
\hline IMP 2 & $\begin{array}{l}327.4\left(\mathrm{M}^{+}+2\right) \\
325.4\left(\mathrm{M}^{+}\right)\end{array}$ & $\begin{array}{c}1312.47(\mathrm{C}-\mathrm{N}) \\
1615.27(\mathrm{C}=\mathrm{N}) \\
1099.35(\mathrm{C}-\mathrm{Cl}) \\
1216.03(\mathrm{C}-\mathrm{F})\end{array}$ & $\begin{array}{c}2.55\left(\mathrm{~s}, 3 \mathrm{H}, \mathrm{CH}_{3}\right), 4.055(\mathrm{~s}, 1 \mathrm{H}, \mathrm{CH}) \\
5.13(\mathrm{~s}, 1 \mathrm{H}, \mathrm{CH}), 6.92-7.545(\mathrm{~m}, 8 \mathrm{H}, \mathrm{ArH})\end{array}$ \\
\hline IMP 3 & $\begin{array}{c}343.3\left(\mathrm{M}^{+}+2\right) \\
341.3\left(\mathrm{M}^{+}\right)\end{array}$ & $\begin{array}{c}1305.72(\mathrm{C}-\mathrm{N}) \\
1531.37(\mathrm{~N}>\mathrm{O}) \\
1098.39(\mathrm{C}-\mathrm{Cl}) \\
1226.64(\mathrm{C}-\mathrm{F})\end{array}$ & $\begin{array}{c}2.584\left(\mathrm{~s}, 3 \mathrm{H}, \mathrm{CH}_{3}\right), 4.9-5.08\left(\mathrm{q}, 2 \mathrm{H}, \mathrm{CH}_{2}\right) \\
7.0-7.48(\mathrm{~m}, 8 \mathrm{H}, \mathrm{ArH})\end{array}$ \\
\hline IMP 4 & $\begin{array}{c}\text { 303.4 }\left(\mathrm{M}^{+}\right) \\
305.4\left(\mathrm{M}^{+}+2\right)\end{array}$ & $\begin{array}{c}1331.76(\mathrm{C}-\mathrm{N}) \\
3360.73,3244.05 \\
\left(\mathrm{NH}_{2}\right) \\
1105.14(\mathrm{C}-\mathrm{Cl}) \\
1216.03(\mathrm{C}-\mathrm{F})\end{array}$ & $\begin{array}{c}\text { DMSO: } 3.261-3.304\left(\mathrm{dd}, 2 \mathrm{H}, \mathrm{CH}_{2}\right), 4.27-4.317 \\
(\mathrm{dd}, 1 \mathrm{H}, \mathrm{CH}), 3.101-3.152\left(\mathrm{dd}, 1 \mathrm{H}, \mathrm{CH}_{2}\right), \\
\left.\text { 3.947-4.029 (d, 1H, } \mathrm{CH}_{2}\right), 6.9-7.8(\mathrm{~m}, 7 \mathrm{H}, \mathrm{ArH}), \\
8.742\left(\mathrm{br}, 2 \mathrm{H}, \mathrm{NH}_{2}\right), 9.282(\mathrm{~s}, 1 \mathrm{H}, \mathrm{NH})\end{array}$ \\
\hline IMP 5 & $\begin{array}{l}290.1\left(\mathrm{M}^{+}+2\right) \\
288.1\left(\mathrm{M}^{+}\right)\end{array}$ & $\begin{array}{c}1685.67(\mathrm{C}=\mathrm{O}) \\
1326.93(\mathrm{C}-\mathrm{N}) \\
3211.26(\mathrm{NH}) \\
1101.28(\mathrm{C}-\mathrm{Cl}) \\
216.03(\mathrm{C}-\mathrm{F})\end{array}$ & $\begin{array}{c}4.361\left(\mathrm{~s}, 2 \mathrm{H}, \mathrm{CH}_{2}\right), 9.758(\mathrm{~s}, 1 \mathrm{H}, \mathrm{NH}) \\
\quad 7.03-7.57(\mathrm{~m}, 7 \mathrm{H}, \mathrm{ArH})\end{array}$ \\
\hline IMP 6 & $\begin{array}{l}273.2\left(\mathrm{M}^{+}+2\right) \\
271.2\left(\mathrm{M}^{+}\right)\end{array}$ & $\begin{array}{l}1320.18(\mathrm{C}-\mathrm{N}) \\
1090.67(\mathrm{C}-\mathrm{Cl}) \\
1227.61(\mathrm{C}-\mathrm{F})\end{array}$ & $\begin{array}{c}2.950\left(\mathrm{~s}, 3 \mathrm{H}, \mathrm{CH}_{3}\right) \\
7.126-7.92(\mathrm{~m}, 7 \mathrm{H}, \mathrm{ArH})\end{array}$ \\
\hline IMP 7 & $\begin{array}{l}329.2\left(\mathrm{M}^{+}+2\right) \\
327.2\left(\mathrm{M}^{+}\right)\end{array}$ & $\begin{array}{c}1349.11(\mathrm{C}-\mathrm{N}) \\
1088.74(\mathrm{C}-\mathrm{Cl}) \\
1208.32(\mathrm{C}-\mathrm{F})\end{array}$ & $\begin{array}{c}1.694\left(\mathrm{~s}, 3 \mathrm{H}, \mathrm{CH}_{3}\right), 3.975-3.998\left(\mathrm{~d}, 2 \mathrm{H}, \mathrm{CH}_{2}\right) \\
4.615-4.672(\mathrm{dt}, 1 \mathrm{H}, \mathrm{CH}), 3.896-3.925 \\
\left(\mathrm{~d}, 1 \mathrm{H}, \mathrm{CH}_{2}\right), 3.436-3.476\left(\mathrm{dd}, 1 \mathrm{H}, \mathrm{CH}_{2}\right) \\
6.96-7.619(\mathrm{~m}, 7 \mathrm{H}, \mathrm{ArH})\end{array}$ \\
\hline IMP 8 & $\begin{array}{l}329.5\left(\mathrm{M}^{+}\right) \\
331\left(\mathrm{M}^{+}+2\right)\end{array}$ & $\begin{array}{c}1321.15(\mathrm{C}-\mathrm{N}) \\
3449.45(\mathrm{NH}) \\
1106.10(\mathrm{C}-\mathrm{Cl}) \\
1223.75(\mathrm{C}-\mathrm{F})\end{array}$ & $\begin{array}{c}1.727\left(\mathrm{~s}, 3 \mathrm{H}, \mathrm{CH}_{3}\right), 4.006-4.033\left(\mathrm{~d}, 2 \mathrm{H}, \mathrm{CH}_{2}\right) \\
4.649-4.706(\mathrm{dt}, 1 \mathrm{H}, \mathrm{CH}), 3.931-3.960 \\
\left(\mathrm{~d}, 1 \mathrm{H}, \mathrm{CH}_{2}\right), 3.469-3.510\left(\mathrm{dd}, 1 \mathrm{H}, \mathrm{CH}_{2}\right) \\
7.8(\mathrm{br}, 1 \mathrm{H}, \mathrm{NH}), 5.173(\mathrm{~s}, 1 \mathrm{H}, \mathrm{CH}) \\
6.938-7.652(\mathrm{~m}, 7 \mathrm{H}, \mathrm{ArH})\end{array}$ \\
\hline
\end{tabular}

IMP 1 and 8 involved reduction of the double bond of midazolam and dihydromidazolam (IMP 7) respectively, when treated with zinc dust as shown in Schemes 1 and 2. ${ }^{1} \mathrm{H}$ NMR spectrum of IMP 1 showed one singlet broad peak at $7.7 \mathrm{ppm}$ due to the $\mathrm{NH}$ group and a singlet for $\mathrm{CH}$ at higher chemical shift (5.147 ppm) because of the deshielding effect of $\mathrm{C}_{6} \mathrm{H}_{5}-\mathrm{F}$. Both peaks arose due to the reduction of the bond between $\mathrm{N}=\mathrm{C}$ in the 1,4-benzodiazepine ring of midazolam. ${ }^{1} \mathrm{H}$ NMR spectrum of IMP 8 showed a singlet peak at $5.173 \mathrm{ppm}$ due to $\mathrm{CH}$ and one more singlet broad peak at $7.8 \mathrm{ppm}$ due 
B. Sati et al: Synthesis of the impurities during the manufacture of bulk drug midazolam and separation of these impurities by HPLC, Acta Pharm. 63 (2013) 385-396.

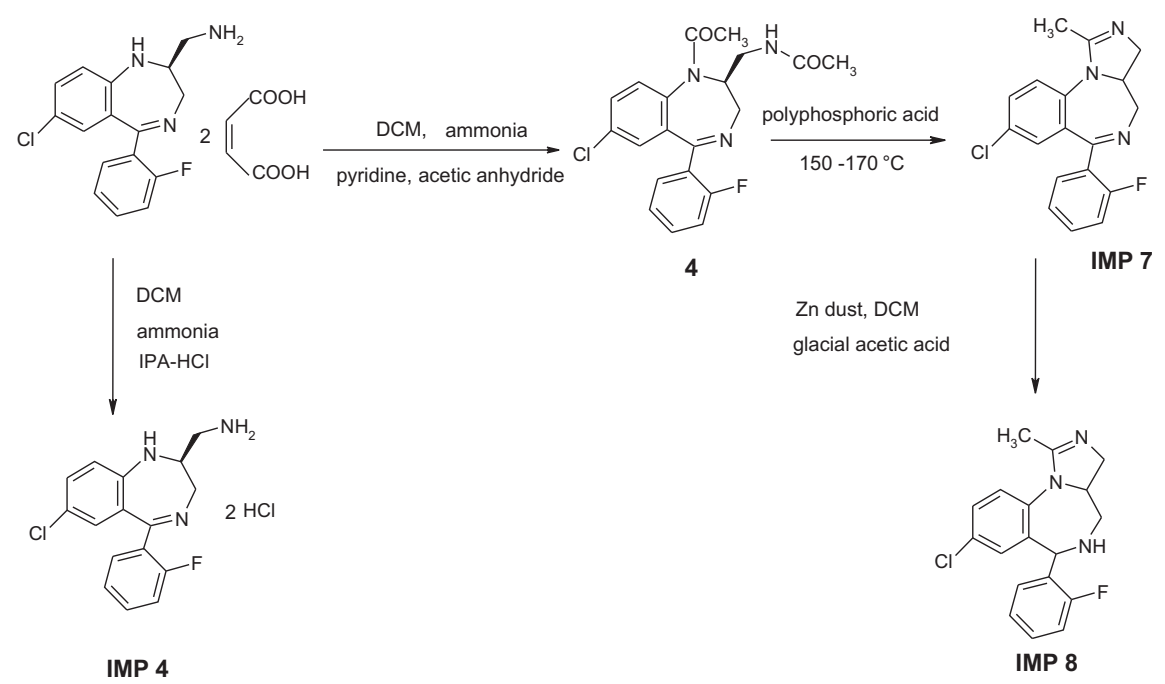

Scheme 2

to the $\mathrm{NH}$ group, indicating reduction of the bond between $\mathrm{N}=\mathrm{C}$ in the 1,4-benzodiazepine ring of dihydromidazolam (IMP 7). Midazolam IMP 2 was synthesized by double bond migration when midazolam was treated with potassium tertiary butoxide and dimethyl-formamide (DMF) at $-30{ }^{\circ} \mathrm{C}$ as shown in Scheme 1. Synthesis of IMP 3 was carried out by oxidation of midazolam by using $m$-chloroperbenzoic acid and DCM as shown in Scheme 1. Both impurities 2 and 3 were further purified by column chromatography using silica gel as an adsorbent and DCM as an eluent. ${ }^{1} \mathrm{H}$ NMR spectrum of IMP 2 showed a singlet at $5.13 \mathrm{ppm}$ for $\mathrm{CH}$ at higher chemical shift because of the deshielding effect of $\mathrm{C}_{6} \mathrm{H}_{5}-\mathrm{F}$ but no absorption peak for $\mathrm{NH}$ indicating migration of the double bond in the 1,4-benzodiazepine ring. IR spectrum of IMP 3 showed $\mathrm{N} \rightarrow \mathrm{O}$ stretching at $1531.37 \mathrm{~cm}^{-1}$ indicating oxidation of the $\mathrm{N}$ group in the 1,4-benzodiazepine ring of midazolam. On the other hand, alkalization of 2-aminomethyl-7-chloro-2,3-dihydro-5-(2-fluorophenyl)-1H-1,4-benzodiazepine dimaleate salt conversion to its hydrochloride salt using hydrochloride in the isopropyl alcohol mixture yielded IMP 4 (Scheme 2). Synthesis of IMP 7 occurred in two steps. The first step involved alkalization of 2-aminomethyl-7-chloro-2,3-dihydro-5-(2-fluorophenyl)-1H-1,4-benzodiazepine dimaleate salt with ammonia and when treated with acetic anhydride underwent acetylation to yield 1-acetyl-2-acetylaminomethyl-7-chloro-2,3-dihydro-5-(2-fluorophenyl)-1H-1,4-benzodiazepine (4). The second step was cyclisation of the acetylated intermediate (4): when heated with polyphosphoric acid it afforded IMP 7 as shown in Scheme 2. ${ }^{1} \mathrm{H}$ NMR spectrum of IMP 7 showed a doublet peak at 3.975-3.998 ppm supporting the methylene protons and a doublet or triplet peak at 4.615-4.672 ppm for $\mathrm{CH}$ indicating that the bond between the $\mathrm{C}=\mathrm{C}$ in the imidazole moiety of midazolam was reduced. Moreover, amidation of 2-amino-5-chloro-2'-fluoro benzophenone, when treated with chloroacetyl chloride, afforded 2-(2-chloro-acetamido)-5-chloro-2'-fluoro benzophenone (1) and this amide underwent cyclisation in the presence of ammonia in methanol to afford IMP 5 (Scheme 3). IR spectrum of IMP 5 showed N-H stretching at $3211.26 \mathrm{~cm}^{-1}$ and $\mathrm{C}=\mathrm{O}$ 
B. Sati et al:: Synthesis of the impurities during the manufacture of bulk drug midazolam and separation of these impurities by HPLC, Acta Pharm. 63 (2013) 385-396.

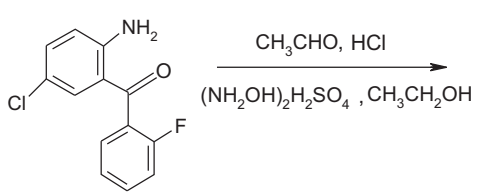

$\mathrm{ClCH}_{2} \mathrm{COCl}$

toluene, $\mathrm{NaHCO}_{3}$<smiles>CC(=O)Nc1ccc(Cl)cc1C(=O)c1ccccc1F</smiles>

1<smiles>CC1Nc2ccc(Cl)cc2C(c2ccccc2F)=[N+]1[O-]</smiles>

2<smiles>O=C1CN=C(c2ccccc2F)c2cc(Cl)ccc2N1</smiles>

IMP 5<smiles>Cc1nc2ccc(Cl)cc2c(-c2ccccc2F)[n+]1[O-]</smiles>

3

$\mathrm{NaBH}_{4}$, methanol

$10^{\circ} \mathrm{C}$<smiles>Cc1nc(-c2ccccc2F)c2cc(Cl)ccc2n1</smiles>

IMP 6

Scheme 3

Table III. ${ }^{13} \mathrm{C}$ NMR Spectral data of synthesized compounds

\begin{tabular}{|c|c|}
\hline Code & ${ }^{13} \mathrm{C} \mathrm{NMR}$ \\
\hline IMP 1 & $\begin{array}{c}20.31\left(\mathrm{CH}_{3}\right), 51.67,63.56,135.17,133.27,132.82 \text { (5C, diazepine), 141.53, } 125.37 \\
(2 \mathrm{C} \text {, imidazol), 147.43, 134.71, 130.21, 129.62, 128.18, 126.57, 125.84, 124.45, 120.36, } \\
119.81(10 \mathrm{C}, \text { Ar-C) }\end{array}$ \\
\hline IMP 2 & $\begin{array}{c}21.43\left(\mathrm{CH}_{3}\right), 57.38,160.23,135.46,132.91,132.13(5 \mathrm{C}, \text { diazepine }), 142.31,124.15 \\
(2 \mathrm{C}, \text { imidazol }), 146.21,136.37,131.47,128.54,128.03,123.72,122.67,122.23,121.38 \\
115.27(10 \mathrm{C}, \mathrm{Ar}-\mathrm{C})\end{array}$ \\
\hline IMP 3 & $\begin{array}{c}20.45\left(\mathrm{CH}_{3}\right), 45.83,112.31,138.42,135.27,127.63 \text { (5C, diazepine), } 140.71,123.62 \\
(2 \mathrm{C}, \text { imidazol }), 152.32,136.25,133.57,130.72,126.48,125.61,125.07,123.32,121.40 \\
116.82(10 \mathrm{C}, \text { Ar-C) }\end{array}$ \\
\hline IMP 4 & $\begin{array}{l}37.29\left(\mathrm{CH}_{2}\right), 51.47,62.31,146.25,137.56,132.84,125.63 \text { (5C, diazepine), 140.52, } \\
134.37,132.19,129.47,125.86,125.26,124.65,123.78,119.54,118.32(10 \mathrm{C}, \mathrm{Ar}-\mathrm{C})\end{array}$ \\
\hline IMP 5 & $\begin{array}{c}56.24,154.38,135.42,130.12 \text { (4C, diazepine), 145.35, 133.28, 130.45, 128.72, 125.54, } \\
124.36,124.01,122.63,120.46,117.29(10 \mathrm{C}, \mathrm{Ar}-\mathrm{C}), 173.41(\mathrm{C}=\mathrm{O})\end{array}$ \\
\hline IMP 6 & $\begin{array}{c}25.31\left(\mathrm{CH}_{3}\right), 114.33,116.74,121.37,123.32,124.38,125.43,126.56,129.57,130.68, \\
133.45,135.27,136.73,137.24,140.35(14 \mathrm{C}, \mathrm{Ar}-\mathrm{C})\end{array}$ \\
\hline IMP 7 & $\begin{array}{c}24.45\left(\mathrm{CH}_{3}\right), 47.62,156.28(2 \mathrm{C} \text {, imidazole }), 54.23,60.45,155.48,140.31,128.65 \\
\text { (5C, diazepine), 150.27, 132.45, 130.53, 129.63, 126.56, 123.45, 121.36, 120.72, } \\
118.25,116.48(10 \mathrm{C}, \text { Ar-C })\end{array}$ \\
\hline IMP 8 & $\begin{array}{c}24.57\left(\mathrm{CH}_{3}\right), 50.23,158.35(2 \mathrm{C}, \text { imidazole }), 51.32,54.26,62.01,140.57,135.41 \\
(5 \mathrm{C} \text {, diazepine }), 152.45,134.25,132.62,130.58,128.35,126.41,123.29,121.87,117.23, \\
115.93(10 \mathrm{C}, \mathrm{Ar}-\mathrm{C})\end{array}$ \\
\hline
\end{tabular}


stretching at $1685.67 \mathrm{~cm}^{-1} .{ }^{1} \mathrm{H}$ NMR showed a singlet at $4.361 \mathrm{ppm}$ supporting the methylene groups and a singlet at $9.758 \mathrm{ppm}$ indicating the NH group. Preparation of IMP 6 involved three steps. The first step was cyclisation as well as oxidation of 2-amino-5-chloro-2'-fluoro benzophenone when treated with acetaldehyde and hydroxyl amine sulphate to yield the dihydroquinazoline-3-oxide (2). The second step was dehydrogenation (2) when treated with activated manganese oxide to get quinazoline-3-oxide (3). The third step involved reduction (3) in the presence of sodium borohydride to yield IMP 6 as shown in Scheme 3. ${ }^{1} \mathrm{H}$ NMR of IMP 6 showed a singlet at 2.950 ppm supporting the methyl protons and multiplet at 7.126-7.92 ppm indicating $7 \mathrm{H}$ of aromatic moiety.

The synthesized impurities (IMP1-IMP8) were structurally elucidated on the basis of spectral data and explained with the example of compound IMP1. The mass spectrum shows the presence of the peak at $\mathrm{m} / \mathrm{z} 327.2$ for $\mathrm{M}^{+}$in accordance with the molecular formula, $\mathrm{C}_{18} \mathrm{H}_{15} \mathrm{ClFN}_{3}$. It also shows the $\left(\mathrm{M}^{+}+2\right)$ peak at $m / z 329.2$ due to the presence of halogen atoms. The structures were also supported by ${ }^{13} \mathrm{C}$ NMR data. The ${ }^{13} \mathrm{C}$ NMR of IMP1 showed peaks at $20.31\left(\mathrm{CH}_{3}\right), 51.67,63.56,135.17,133.27,132.82$ (5C, diazepine), 141.53, 125.37 (2C, imidazole), 147.43, 134.71, 130.21, 129.62, 128.18, 126.57, $125.84,124.45,120.36$ and 19.81 (10C, Ar-C) to confirm its structure. The other impurities were identified in a similar manner. In IMP 4, 5 and $6,{ }^{13} \mathrm{C}$ NMR showed no peaks for carbons of the imidazole ring, showing the absence of imidazole ring. ${ }^{13} \mathrm{C}$ NMR of IMP 5 showed the peak at 173.41 for the presence of $\mathrm{C}=\mathrm{O}$ group. In IMP $\mathbf{6}$ the total 14 carbon peaks showed the presence of the quinazoline ring along with the phenyl ring.

RP-HPLC method. - Several mobile phase compositions were assayed for the separation of impurities from midazolam. Satisfactory separation of midazolam and all its eight impurities was obtained with mobile phase consisting of dipotassium hydrogen phosphate buffer ( $\mathrm{pH}$ adjusted to 3.29 using dilute ortho phosphoric acid)/acetonitrile/ methanol $(71.45: 20.7: 7.85, V / V / V)$. Chromatogram of the impurities mixture is shown in Fig. 1.

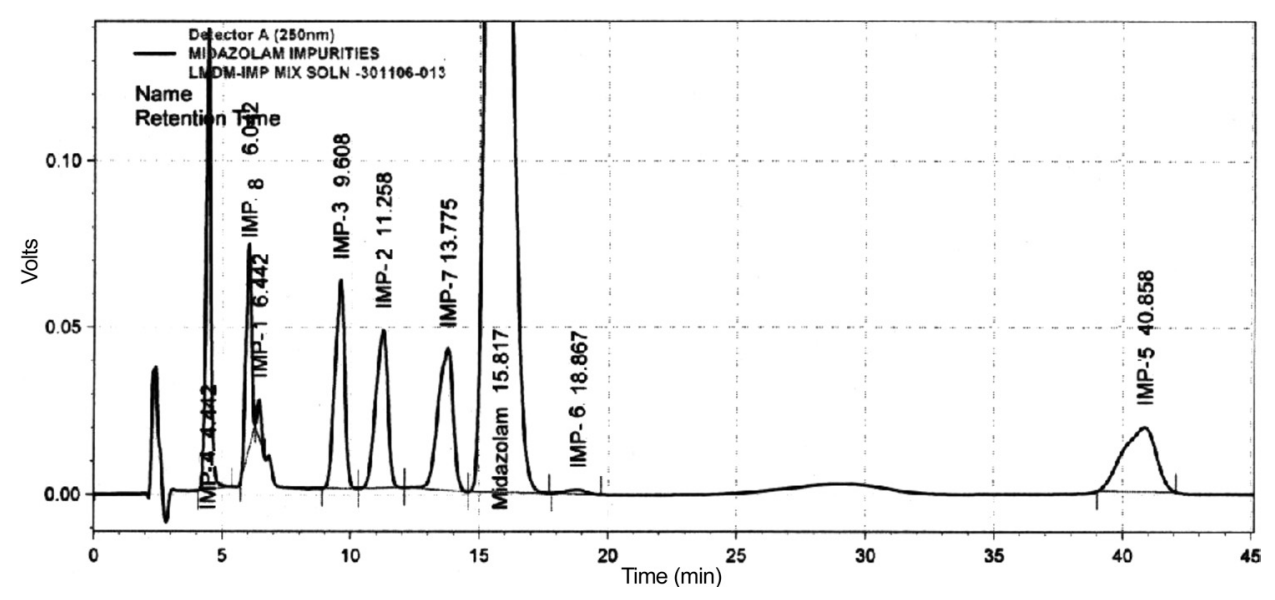

Fig. 1. Separation of mixture of impurities of midazolam. The first peak is of solvent methanol. 
B. Sati et al: Synthesis of the impurities during the manufacture of bulk drug midazolam and separation of these impurities by HPLC, Acta Pharm. 63 (2013) 385-396.

Parameters including the retention time, area, area midazolam resolution, capacity factor, separation factor, asymmetry factor, HETP and number of theoretical plates are listed in Table IV. Individual chromatogram of each impurity was also taken. The retention time of individual impurities is given in Table I.

Table IV. Parameters for the RP-HPLC method

\begin{tabular}{lccccccccc}
\hline & \multicolumn{1}{c}{ IMP } \\
\cline { 2 - 10 } Parameters & 4 & 8 & 1 & 3 & 2 & 7 & $\begin{array}{l}\text { Mida- } \\
\text { zolam }\end{array}$ & 6 & 5 \\
\hline $\begin{array}{l}\text { Retention } \\
\text { time (min) }\end{array}$ & 4.442 & 6.042 & 6.442 & 9.608 & 11.258 & 13.775 & 15.817 & 18.867 & 40.858 \\
$\begin{array}{l}\text { Resolution } \\
\text { Asymmetry }\end{array}$ & 0.00 & 4.31 & 1.15 & 6.36 & 2.06 & 2.55 & 1.44 & 1.93 & 10.97 \\
$\begin{array}{l}\text { Capacity } \\
\text { factor }\left(k^{\prime}\right)\end{array}$ & 0.67 & 1.27 & 1.42 & 2.61 & 3.23 & 4.18 & 4.95 & 6.09 & 14.36 \\
$\begin{array}{l}\text { Separation } \\
\text { factor }(\alpha)\end{array}$ & 0.00 & 1.89 & 1.12 & 1.84 & 1.24 & 1.29 & 1.18 & 1.23 & 2.36 \\
$\begin{array}{l}\text { HETP } \\
N\end{array}$ & 0.00792 & 0.00466 & 0.0041 & 0.0299 & 0.0274 & 0.0227 & 0.0249 & 0.01209 & 0.00508 \\
$N$ & 315.70 & 5363.56 & 6097.24 & 834.99 & 913.41 & 1101.76 & 1000.70 & 2066.85 & 4919.96 \\
\hline
\end{tabular}

HETP - height equivalent of the theoretical plate.

$N$ - number of theoretical plates.

\section{CONCLUSIONS}

The eight impurities that can be present along with the bulk drug midazolam were synthesized. A RP-HPLC method was developed for separation of a mixture of eight impurities from the bulk drug midazolam HPLC. The result showed satisfactory separation of impurities, except for IMP 1 and $\mathbf{8}$ which were not separated properly. The work is in progress to develop and validate a more selective method for the separation of all impurities with good resolution.

\section{REFERENCES}

1. International Conference on Harmonisation of Technical Requirements for Registration of Pharmaceuticals for Human Use, ICH Harmonised Tripartite Guideline - Impurities: Guideline for residual solvents: Text and Methodology Q3C(R5), Current Step 4 version, London 2011.

2. S. Ahuja, Impurities Evaluation of Pharmaceuticals, Marcel Dekker, New York 1998, pp. 1-41.

3. International Conference on Harmonisation of Technical Requirements for Registration of Pharmaceuticals for Human Use, ICH Harmonised Tripartite Guideline - Validation of Analytical Procedures: Text and Methodology Q2(R1), Current Step 4 version, London 2005. 
B. Sati et al: Synthesis of the impurities during the manufacture of bulk drug midazolam and separation of these impurities by HPLC, Acta Pharm. 63 (2013) 385-396.

4. S. Gorog, M. Babjak, G. Balogh, J. Brlik, A. Csehi and F. Dravecz, Drug impurity profiling strategies, Talanta 44 (1997) 1517-1526.

5. J. Claassen, L. J. Hirsch, R. G. Emerson and S. A. Mayer, Treatment of refractory status epilepticus with pentobarbital, propofol, or midazolam: A systematic review, Epilepsia 43 (2002) 146153.

6. G. Hsiao, M. Y. Shen, D. S. Chou, Y. Chang, L. W. Lee, C. H. Lin and J. R. Sheu, Mechanisms of antiplatelet and antithrombotic activity of midazolam in in vitro and in vivo studies, Eur. J. Pharmacol. 487 (2004) 159-166; DOI: 10.1016/j.ejphar.2004.01.026.

7. D. F. Hanley and J. F. Kross, Use of midazolam in the treatment of refractory status epilepticus, Clin. Therap. 20 (1998) 1093-1105.

8. E. E. Irvine, S. Cheeta, C. Lovelock and S. E. File, Tolerance to midazolam's anxiolytic effects after short-term nicotine treatment, Neuropharmacology 40 (2001) 710-716; DOI: 10.1016/S00283908(00)00211-2.

9. S. L. Eeckhoutd, J. P. Desager, Y. Hormansy, A. J. Winne and R. K. Verbeeck, Sensitive assay for midazolam and its metabolite 1'-hydroxy midazolam in human plasma by capillary high performance liquid chromatography, J. Chromatogr. B 710 (1998) 165-171.

10. J. Jurica, M. Dostalek, J. Konecny, Z. Glatz, E. Hadasova and J. Tomandl, HPLC determination of midazolam and its three hydroxy metabolites in perfusion medium and plasma from rats, J. Chromatogr. B 852 (2007) 571-577; DOI: 10.1016/j.jchromb.2007.02.034.

11. S. N. Muchohi, S. A. Ward, L. Preston, C. R. J. C. Newton, G. Edwards and G. O. Kokwaro, Determination of midazolam and its major metabolite 1 '-hydroxymidazolam by high-performance liquid chromatography-electrospray mass spectrometry in plasma from children, J. Chromatogr. B 821 (2005) 1-7; DOI: 10.1016/j.jchromb.2005.03.015.

12. X. Xue, M. Huang, H. Xiao, X. Qin, L. Huang, G. Zhong and H. Bi, Rapid and simultaneous measurement of midazolam, 1'-hydroxymidazolam and digoxin by liquid chromatography/ tandem mass spectrometry: Application to an in vivo study to simultaneously measure P-glycoprotein and Cytochrome P450 3A activity, J. Pharm. Biomed. Anal. 55 (2011) 187-193; DOI: 10. 1016/j.jpba.2011.01.018.

13. M. R. Shiran, A. Gregory, A. R. Hodjegan, G. T. Tucker and M. S. Lennard, Determination of midazolam and 1'-hydroxymidazolam by liquid chromatography-mass spectrometry in plasma of patients undergoing methadone maintenance treatment, J. Chromatogr. B. 783 (2003) 303-307; DOI: 10.1016/S1570-0232(02)00673-6. 